表 2 治療期間と抗原濃度

\begin{tabular}{|c|c|c|c|c|}
\hline \multirow{2}{*}{ 抗原濃度 } & & 期 & 間 & \multirow{2}{*}{ 計 } \\
\hline & 1 年末満 & 2 年末満 & 2 年以上 & \\
\hline $10^{1}$ 倍 & 0 例 $(0.0 \%)$ & 1 例 $(0.8 \%)$ & 2 例 $(1.9 \%)$ & 3 例 ( $0.8 \%)$ \\
\hline $10^{2}$ 倍 & 10例 $(6.8 \%)$ & 30 例 (24.2\%) & 36 例 (34.0\%) & 72 例 (20.2\%) \\
\hline $10^{3}$ 倍 & 12例 $(8.2 \%)$ & 21 例 (16.9\%) & 17 例 $(16.0 \%)$ & 50 例 (13.3\%) \\
\hline $10^{4}$ 倍 & 13 例 $(8.8 \%)$ & 10 例 $(8.1 \%)$ & 10 例 $(9.4 \%)$ & 33例 $(8.8 \%)$ \\
\hline \multirow[t]{2}{*}{$10^{5}$ 倍 } & 112 例 $(50.0 \%)$ & 62 例 (38.7\%) & 41 例 $(57.0 \%)$ & 215 例 (76.2\%) \\
\hline & 147 例 (39.0\%) & 124例(32.9\%) & 106 例 (28.1\%) & 377例 \\
\hline
\end{tabular}

治療期間と改善度

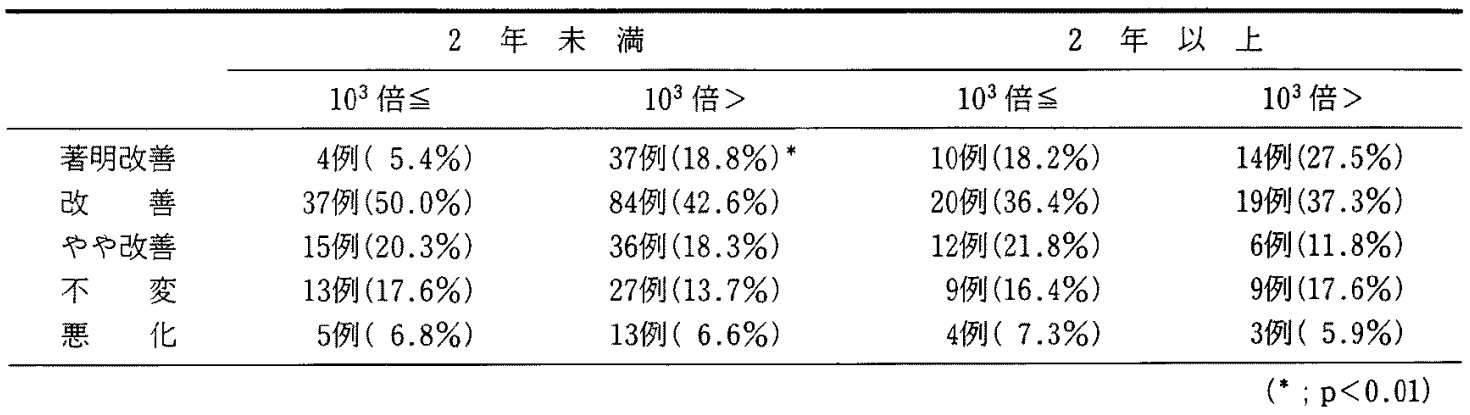

であった。これら 2 群について臨床的に検討した。

結果および考案 平均年齢は，高濃度群では 11.7 歳 ( $3-64$ 歳), 低濃度で群では 12.8 歳 $(3-59$ 歳) で, 年齢分布では，両群間に差は認められなかった。重症 度では，低濃度群で重症50例 (20.2\%) と低濃度群の 12例 $(9.3 \%)$ に比して有意に高功た $(\mathrm{P}<0.01)$ (表 1). しかし, 病型やアレルギー検査成績では両群間に 差は認められなかった。これらアレルギー検査成績の 治療前後変化では, 両群共に有意差は認められなかっ た、気管支喘息・アトピー性皮膚炎やアレルギー性結 膜炎などの他のアレルギ一疾患の合併は，高濃度群で 36 例 $(27,9 \%)$, 低濃度群で80例 $(32.2 \%)$ であり, 合 併率やその内訳では両群間に差は認められなかった。 減感作に伴う副作用では, 高濃度群で局所の発赤・硬 結や水泡形成などの皮膚症状が10例 $(52.6 \%)$ と，低 濃度群で喘息発作の誘発が 6 例 $(30.0 \%)$ と多かった。
これら副作用は必ずしも高濃度で生じるとは限らず， 低濃度群の喘息発作誘発症例 9 例では，ともに $10^{5}$ 倍 の抗原濃度で発作が誘発されていた，減感作治療期間 と抗原濃度の関保では, 治療期間の長い者ほど高濃度 である傾向であったが， 2 年以上治療を受けた 41 例 (57.0\%)で，いまだ105倍であった（表 2)。これら症 例の内34例は15歳末満の小児で, 13例に気管支喘息の 合併を認め，減感作による明らかな発作誘発のため抗 原量の增量が出来なかった。症状改善度は377例中230 例 $(61.0 \%)$ に認められた。症状の消失を含む著明改 善は，低湿度群で $20.6 \%$ と高濃度群の $10.9 \%$ に比して 有意に高かったが $(\mathrm{p}<0.01)$, 改善以上では両群間に 差は認められなかった。. 以上の結果から, 抗原增量困 難症例でも，必ずしも高濃度抗原維持でなくとも，各 症例の臨床状態に合わせた抗原量の設定により十分な 治療効果が期待出来ると推察される.

\title{
3. 副鼻腔気管支症候群
}

\section{司会島田 和 哉（慈大）}

副鼻腔気管支症候群の病因・治療法の解明に関して は，上気道と下気道の相互の関連性についての配虑が 必要である。しかしながら，私共耳鼻科医は，鼻副鼻 腔の病態に関しては，ある程度の知識を持ち合わせて いるが，一般に下気道の病態や上気道病態との結びつ きの検索については，日常耳鼻咽喉科の臨床では不十
分な面があることも否定出来ないと考えられる，本症 に限らず複数科が関係する疾患についての研究は，各 科がその立場を異にすることや横の連絡がつきにくい こともあって，共同研究が円滑に行われ難いこともし ばしば見受けられる。

本症の治療につなげるための病態の把握には、気道 
粘膜の病理組織学・生理学的な基䃈的研究から臨床面 では気道防御機構, 肺機能, 気管支病変, 副鼻腔病変 についての検討が必要とされる。

上記の点を考慮して, 耳鼻咽喉科領域における基礎 的・臨床的な解折，内科・小児科より各々の立場ての 考え方について報告・检討する必要性を痛感した。

そこで次に簡単に紹介するように各分野でこれらの 問題について専門的に研究, 治㙩にあたっておられる 先生方に参加していただいた（耳鼻科関係者は所属を 略す)。

耳鼻科の基礎的な立場として鵜飼先生にはこれまで の上気道の粘液線毛機能の研究の成果に今回は下気道 に慢性の炎症を有する症例についての鼻粘膜の粘液線 毛機能と臨床所見の比較検討が加えられた。ささらに下 気道の粘膜についても生理学的な新しい知見を加えて 報告される予定である。

耳鼻咽喉科の立場より，洲崎・白橎两先生には特に 病因論についてお願いした。洲崎先生は，これまで経 験した多くの症例の分折の中から体質的素因の関与に ついて着目し, 本症例の家族歴, HLA 抗原の検討によ
り発症は遗伝的体質を基礎としているとしている。 白幡先生は病態面で, 副覺空病変と気管支炎とは相 互に関連があることを疫学的・X線学的に検討した結 果を報告する。

吉田先生（日医大・小児科）には小児の気管支喘息， 気管支拡張症の症例の分折加前頭洞 - 上顎洞の発育 程度，病変との関連性について言及される、特に本症 は小児の篗急が多いために，小視科側からの検討結果 加期待される。

岡野先生（慈大・内科）は，びまん性沉細気管支炎 の症例について副鼻腔炎との関連性，睘下性びまん性 細気管支炎について述べられる。

副鼻腔気管支症候群は，副鼻腔炎と気管支の慢性炎 症との合併のみならず, Kartagener 症侯群, immortile cilia Syndrome，先天性免疫不全症候群等気管支に関 連する疾䒇等も含めて広く考えられている。特に今回 は私共と内科的な考え万についての討論と共に内科, 小見科の立場より耳鼻科の盲点についても教えていた だようにしたい。

\section{（1）上・下気道における粘液瀻毛機能}

\section{鵜 飼 幸太郎（三重大）}

副鼻腔気管症候群 (SBS) の発生機序を解明する手 口として粘液緎毛系の面から検討した。すなわち自覚 症状，レ線所見から 1)。対照群（上気道・下気道に炎 症を有さない群）2）。副鼻腔炎群（上気道に慢性炎症 を有するが，下気道に炎症所見をみとめない群），3）. 気管支炎群 (下気道に慢性炎症性疲患をみとめるが上 気道に炎症所見をみとめない群)，4），副鼻腔炎十気管 支炎群（上気道・下気道ともに慢性の炎症をみとめる 群て，びまん性沉紐気管支炎も含む，の4群を検討す 対象とした。

粘液蟣毛機能は粘液流動速度，または粘液輸送時間， 瀻毛打頻度, 粘液のレオロジ一的性状について検討し た. 測定方法は上気道においては鼻中隔にサッカリン 顆粒を招き咽頭に甘味を感ずるでに要するサッカり
ン時間，同側の鼻中隔粘膜を特製ブラシで擦過して得 られた繊毛細胞を in vitroのチャンバー内に移し，ツ アイスの顕微鏡に接続された光電管をとおして测定す る瀻毛打頻度(CBF)，および鼻腔に貯留する疉汁を吸 引によって採取し当教室が開発した磁気振動球レオメ ターを用いて動的粘性率 $\eta^{\prime}$ ，動的弾性率 G'を測定し た。下気道においては，下咽頭，㬋頭，気管に4\%キ シロカインを用いて軽度麻酔したあと，ブロンコファ イバーを気管分岐部まで挿入，側管より付属の細胞診 用ブラシを插入し，食用緑色色素を気管尔岐部直下の 左主気管支に塗布し一定時間内に移動する距離をデジ タルタイマー付きテレビモニターを用いて測定し粘液 流動速度とした。同時にブラシで同部位を擦過するこ とにより鼻と同様の方法で CBFを測定した。また同

表 1 上気道の粘液瀻毛機能

\begin{tabular}{|c|c|c|c|c|}
\hline & 対 & 副鼻腔炎 & 気管支炎 & 副鼻腔炎+気管支炎 \\
\hline サッカリン時間 & $\begin{aligned} 27 \pm & 15 \text { 分 } \\
& (n=16)\end{aligned}$ & $\begin{array}{l}42.0 \pm 38.9 \\
(n=38)^{* *}\end{array}$ & $\begin{array}{l}20 \pm 17 \\
(n=8)^{*}\end{array}$ & $\begin{array}{c}45 \pm 27 \\
(n=7)^{*}\end{array}$ \\
\hline 緎毛打頻度 & 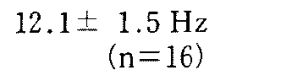 & $\begin{array}{l}11.6 \pm 1.6 \\
(n=23)\end{array}$ & $\begin{array}{l}12.0 \pm 2.7 \\
(n=8)\end{array}$ & $\begin{array}{l}12.2 \pm \\
(n=7)\end{array}$ \\
\hline 動的粘性率 $\eta^{\prime}$ & 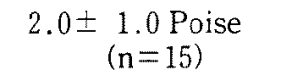 & $\begin{array}{l}25.0 \pm 7.8 \\
(n=15)^{*}\end{array}$ & $\begin{array}{l}3.7 \pm 2.0 \\
(n=7)\end{array}$ & $\begin{array}{l}25.5 \pm 7.5 \\
(n=6)^{*}\end{array}$ \\
\hline 動的弾性率 G' & $\begin{array}{c}50 \pm 28 \quad \text { dyne } / \mathrm{cm}^{2} \\
(\mathrm{n}=15)\end{array}$ & $\begin{array}{l}450 \pm 158 \\
(n=15)^{*}\end{array}$ & $\begin{array}{c}100 \pm 36 \\
(n=7)^{*}\end{array}$ & $\begin{array}{c}480 \pm 190 \\
(n=6)^{*}\end{array}$ \\
\hline
\end{tabular}

$\nVdash p<0.005, \approx p<0.01$ 